$$
\begin{aligned}
& \text { УДК 34:378.6(518)(091) } \\
& \text { https://doi.org/10.24866/1813-3274/2021-2/79-87 }
\end{aligned}
$$
А. А. Хисамутдинов ${ }^{1}$, Дальневосточный федеральный университет,
г. Владивосток, Россия
E-mail:khisamut@yahoo.com

Чи Юйчао르, Дальневосточный федеральный университет,

г. Владивосток, Россия

E-mail: 88002978@qq.com

\title{
ЮРИДИЧЕСКОЕ ОБРАЗОВАНИЕ НА СЕВЕРО-ВОСТОКЕ КИТАЯ (НАЧАЛО ХХ В.)
}

Аннотация. Статья посвящена юридическому образованию на северо-востоке Китая. Подготовка юристов в Китае началась с открытия в Пекине университета Тунвэньгуань (1862). Вначале это учебное заведение поставило цель научить общению с зарубежными странами. С дальнейшим развитием Китая появились большие потребности в подготовке современных юристов и политологов. Особое внимание в статье обращено на деятельность Юридического факультета в Харбине, который был основан Государственным Дальневосточным университетом (г. Владивосток, Россия). Появились дисциплины: коммерческое право, уголовное право, гражданское право. Профессора и преподаватели Юридического факультета создали научную школу в Китае. Большую роль в этом сыграли: Н. В. Устрялов, Н. И. Миролюбов, Г. К. Гинс, В. А. Рязановский, В. В. Энгельфельд, А. А. Камков, Г. Г. Тельберг, С. Ф. Кичин, Е. Х. Нилус, Н. А. Стрелков, Г. Г. Авенариус, Н. Е. Эсперов, М. А. Гильчер, Ф. А. Вальден, М. М. Шалабанов и другие. Статья написана с использованием материалов из зарубежных архивов и библиотек.

Ключевые слова: юриспруденция в Китае, подготовка юристов на северовостоке Китая, Государственный Дальневосточный университет (г. Владивосток, Россия), русские эмигранты-юристы в Китае, Юридический факультет в Харбине, высшее образование на Дальнем Востоке, юридическое образование.

\footnotetext{
${ }^{1}$ Амир Александрович Хисамутдинов, доктор исторических наук, профессор, Школа искусств и гуманитарных наук. Дальневосточный федеральный университет, г. Владивосток, Россия.

2 Чи Юйчао, аспирант департамента истории и археологии, Школа искусств и гуманитарных наук. Дальневосточный федеральный университет, г. Владивосток, Россия.

Для цитирования: Хисамутдинов А. А., Чи Юйчао. Юридическое образование на северо-востоке Китая (начало XX в.) // Азиатско-Тихоокеанский регион: экономика, политика, право. 2021. №. 2. С. 79 87. DOI https://doi.org/10.24866/1813-3274/2021-2/79-87.
}

(C) Хисамутдинов А. А., Чи Юйчао, 2021 
Amir A. Khisamutdinov ${ }^{1}$, Far Eastern Federal University, Vladivostok, Russia

Chi Yuchao², Far Eastern Federal University, Vladivostok, Russia

\section{LEGAL EDUCATION IN NORTHEAST CHINA (EARLY 20th CENTURY)}

Abstract. The article is devoted to legal education in northeast China. The training of lawyers in China began with the opening of the Tongwenguan University in Beijing (1862). Initially, this educational institution set a goal to teach communication with foreign countries. With the further development of China, there was a great need for the training of modern lawyers and political scientists. Particular attention in the article is paid to the activities of the Faculty of Law in Harbin, which was founded by the State Far Eastern University in Vladivostok. Disciplines appeared: commercial law, criminal law, civil law. Faculty of Law professors and faculty set up a science school in China. An important role in this was played by: N. V. Ustryalov, N. I. Mirolyubov, G. K. Hins, V. A. Ryazanovsky, V. V. Engelfeld, A. A. Kamkov, G. G. Telberg, S. F. Kichin, E. Kh. Nilus, N. A. Strelkov, G. G. Avenarius, N. E. Esperov, M. A. Guilcher, F. A. Walden, M. M. Shalabanov and others. The article was written using materials from foreign archives and libraries.

Key words: jurisprudence in China, training of lawyers in northeast China, State Far Eastern University (Vladivostok, Russia), Russians emigrant lawyers in China, Faculty of Law in Harbin, higher education in the Far East, legal education.

Юридическое образование европейского стандарта в Китае началось и развивалось во время первых международных конфликтов в этой стране [7]. После Первой опиумной войны (1840) Китай вынудили подписать ряд неравноправных договоров, направленных против суверенитета страны. Тогда и стало формироваться новое юридическое образование в Китае, началась первая подготовка специалистов по юриспруденции, знакомых с западной правовой системой.

После Второй опиумной войны (1860) правительство Цинской династии учредило Управление премьер-министра по национальным делам, которое стало отвечать за дипломатические отношения. В 1862 г. фракция движения «Ян-У» (сторон-

\footnotetext{
${ }^{1}$ Amir A. Khisamutdinov, Doctor of Historical Sciences, Professor, School of Arts and Humanities, Far Eastern Federal University, Vladivostok, Russia.

${ }^{2}$ Chi Yuchao, postgraduate Student, Department of History and Archeology, School of Arts and Humanities, Far Eastern Federal University, Vladivostok, Russia.

For citing: Khisamutdinov A. A., Chi Yuchao. Legal education in northeast China (early 20th century) // Pacific RIM: Economics, Politics, Law. 2021. No 2. P. 79-87. DOI 9 https://doi.org/10.24866/18133274/2021-2/79-87.
} 
ники развития международных отношений и отраслей капиталистической промышленности) открыла в Пекине университет Тунвэньгуань (кuт. 同文馆), в котором китайцы учились иностранным языкам и другим общественным наукам, имеющим отношение к юриспруденции. В 1864 г. священник американской пресвитерианской церковь Дин Шилян (William Alexander Parsons Martin, 1827-1916, Пекин) был преподавателем английского языка в университете Тунвэньгуань. В 1869 г. он стал заведующим учебными делами в университете Тунвэньгуань и читал курс «Основные принципы международного права». В 1863 г. Дин Шилян перевел на китайский язык книгу «Elements of International Law» (автор Henry Wheaton - юрист, 17851848). После издания этой монографии в Тунвэньгуань начался этап открытия учебных курсов по международному праву и подготовке соответствующих специалистов. Так, в Тунвэньгуане впервые изменилось традиционное феодальное образование и был сделан первый шаг в подготовке юристов, знающих международное право [12].

В 1904 г. в городе Баодин открылся Университет права и политики провинции Хэбэй в Китае (直隶法政学堂 Zhi Li Fa Zheng Xue Tang), с которого и началось современное юридическое образование в Китае. В это учебное заведение в основном принимали чиновников, которые уже служили в правительстве Китая, началась подготовка специалистов со знанием права и политологии [5, с. 50].

Уже к 1909 г. в Китае было открыто 47 местных университетов права и политики, в которых обучалось 12282 студентов, что составляло 37\% от общего числа университетов и 52\% от общего числа студентов в Китае [10, с. 499-502].

Китайский исследователь Ван Цзянь отмечает: «С середины 19 века до образования Нового Китая, середины 20 века, «Западная» правовая традиция бросила вызов Китаю. Китай начинал путь реформ и усиления под огромным давлением западных держав. Россия в качестве части системы западной цивилизации также участвовала в процессе влияния и изменения судьбы современного Китая. В процессе реформирования законов в конце династии Цин «российское уголовное право», «российское гражданское право» и другие нормативные акты были переведены на китайский язык, став важными справочными материалами для правительства династии Цин при разработке новых законов и правил. Китайский эксперт по юриспруденции Цзи Тунцзюнь (1854-1936), который работал в Министерстве наказаний (уголовных дел до 1906), представил аналитический отчёт о пересмотре закона (1904). В нём он неоднократно цитировал «Русские законы», а также ряд уложений о наказаниях в других странах, сравнивая их с Дацином люйли (сводом уголовных законов империи Цин, 1646 г.), предлагая удалить строгие законы, суровые наказания и смягчить уголовное право. Правительство Цин приняло эти рекомендации» [11, с. 92-95].

В 1905 г. руководитель провинциального Хэйлунцзяна (северо-восток Китая) Чэн Дэцюань (1860-1930, Шанхай) основал первое высшее юридическое учебное 
заведение провинции Хэйлунцзяна в Цицикаре - Хэйлунцзянский университет права и политики (黑龙江法政学堂, Hei long Jiang Fa Zheng Xue Tang). Этот университет принимал в основном служащих, которые работали в военных учреждениях, всего 70 студентов. Выпускник частного университета права и политики в Японии Чэнь Мо стал первым ректором. Ли Дай пишет: «В 1907 году в связи с неразберихой в делах по приёму учащихся, экзамену, часть преподавателей забастовали. Тогда Чэн Дэцюань отдал распоряжение о закрытии университета» [1, с. 12]. В 1910 г. Хэйлунцзянский университет права и политики возобновил занятия по подготовке специалистов по административной юстиции. Около ста студентов учились на юридическом и политологическом факультетах. Большинство преподавателей получили образование в Университете права и политики в Японии. Также к преподаванию были привлечены китайские судьи.

Университет просуществовал более года и закрылся из-за чумы. В 1912 г. на базе бывшего Хэйлунцзянского университета права и политики открыли Специальное учебное заведение права и политики (法政专门学校, Fa Zheng Zhuan Men Xue $\mathrm{Xiao)} \mathrm{с} \mathrm{тремя} \mathrm{отделениями:} \mathrm{юридический,} \mathrm{политологический} \mathrm{и} \mathrm{экономический.} \mathrm{Со-}$ гласно требованиям Министерства образования Китая, срок обучения бакалавра составлял три года, преподавались дисциплины: конституция, административное право, международное право, уголовное право, гражданское право, коммерческое право, процессуальное право, политология, экономика, финансы и статистика $[1$, c. 13]. В 1929 г. Специальное учебное заведение права и политики закрылось, а студентов отправили в Шэньян, Бэйпин (название Пекина с 1928 г. до 1949 г.) для продолжения учёбы.

В 1920 г. Русские эмигранты-юристы открыли Юридический факультет в Харбине, который получил аккредитацию от Государственного Дальневосточного факультета (ГДУ) (г. Владивосток). За основу учебного курса была взята программа юридических факультетов императорской России. При этом имелись и региональные отличия, связанные с Китаем, его экономикой и подготовкой специалистоввостоковедов.

Юридический факультет состоял из Юридического отделения, в составе которого имелись юридический и восточно-юридический подотделы и Экономического отделения с коммерческим и восточно-экономическим подотделами.

Юридическое отделение имело целью дать слушателям общее юридическое образование, дополненное изучением государственного языка и действующего в Маньчжу-Ди-Го права. Восточно-юридический подотдел давал, главным образом, практическую подготовку, связанную с юридической профессией.

Помимо известных профессоров, таких как Николай Васильевич Устрялов (1890-1937, Москва), Никандр Иванович Миролюбов (1870-1927, Харбин), Георгий Константинович Гинс (1887-1971, США), Валентин Александрович Рязанов- 
ский (1884-1968, США) и Владимир Викторович Энгельфельд (1891-1937, Харбин), на факультете работало немало знатоков юриспруденции.

Опытным военным юристом был Александр Александрович Камков (1868 после 1937) (4). Он окончил юридическое отделение Императорского Казанского университета (1889), военно-учебный курс Московского пехотного юнкерского училища (1891) и Александровскую военно-юридическую академию по 1-му разряду (1896). В военную службу он вступил подпоручиком в октябре 1889 г. В 1895 г. Камков защитил диссертацию на звание магистра уголовного права в Казанском университете. Он был участником подавления Боксёрского восстания в Китае в 1900-1901 гг. и Русско-японской войны 1904-1905 гг., награждён многими орденами. Некоторое время А. А. Камков служил военным судьёй Приамурского военноокружного суда.

В годы Гражданской войны Александр Александрович исполнял должность председателя Приамурского военно-окружного суда (1919) и председателя уголовного департамента Владивостокской судебной палаты (1920). Во Владивостоке А. А. Камков стал доцентом по кафедре уголовного права ГДУ (1920-1921).

25 октября 1922 г. А. А. Камков с семьёй эвакуировался в составе эскадры адмирала Г. К. Старка из Владивостока в Гензан. Оттуда они выехали в Харбин. Александр Александрович был преподавателем (с 1926 г.), секретарём (с 1929 г.) и заместителем декана (с 1930 г.) Юридического факультета в Харбине.

Заметный след на Юридическом факультете оставил профессор Георгий Густавович Тельберг (1881-1954, Нью-Йорк) [5, с. 50]. Он окончил юридический факультет Казанского университета. В Московском университете Тельберг получил степень магистра истории русского права (1912). Г. Г. Тельберг был лектором по русской истории и юридическим древностям в Московском археологическом институте и в Московском университете (1912-1913), профессором по кафедре истории русского права Томского университета (1913-1917), затем деканом юридического факультета Саратовского университета. На Юридическом факультете в Харбине Тельберг вёл занятия по истории права. Он обращал большое внимание на учебную литературу, подготовив серию учебных пособий «Церковные уставы древних царей» (Харбин, 1928); «Русская Правда» (Харбин, 1926); «Речевые судебные грамоты. Псковская и Новгородская» (Харбин, 1926); «Судебники Великого князя Ивана III и царя Ивана IV» (Харбин, 1926) и др.

Опытным юристом-практиком был Сергей Федорович Кичин. Он окончил юридическое отделение Санкт-Петербургского университета. В 1921 г. его назначили председателем Владивостокского окружного суда. Он также был генералпрокурором Приамурского земского края и помощником правителя рати по гражданской части. На Юридическом факультете С. Ф. Кичин вёл курс уголовное право и уголовный процесс. Он опубликовал учебное пособие «Преступление против 
имущества в китайском праве: поджог, наводнение и порча водных систем», «Из лекций по уголовному праву Китая» (Харбин, 1927).

Свой вклад в Юридический факультет внёс и военный юрист-историк Евгений Христофорович Нилус (1880-1951, Швейцария). Он окончил 2-й Московский кадетский корпус (1898), Михайловское артиллерийское училище (1901) и Александровскую военно-юридическую академию (1910). Много лет Нилус служил в Харбине: военный судья (с декабря 1914), старший офицер для поручений у генерала Д. Л. Хорвата (1920), агент по юридическим делам Китайско-восточной железной дороги (1921-1930). В основном он занимался составлением «Исторического обзора Китайско-восточной железной дороги, 1896-1923 гг.» (Харбин, 1923), который является важнейшим источником по деятельности дороги на первом этапе. Издание 1-го тома было приурочено к 25-летию КВЖД, 2-й том остался в рукописи. На факультете Е. Х. Нилус вел занятия по судебному красноречию.

Одним из соучредителей Юридического факультета в Харбине был Николай Арсеньевич Стрелков (1879-?). После окончания философского отделения Московского университета с дипломом 1-й степени (1913) он преподавал русский язык, литературу и логику в харбинских коммерческих училищах; деятельно занимался журналистикой: помощник редактора газеты «Харбинский вестник» и журнала «Вестник Маньчжурии» (с 1917), сотрудник «Русского голоса» (с 1920). С 1 октября 1921 г. Н. А. Стрелков стал приват-доцентом и затем доцентом по кафедре философии ГДУ. Он вёл занятия по общей теории права (1920-1921), социологии и педагогики (1924-1929).

Уникальным специалистом был Георгий Георгиевич Авенариус (1876-1948, Далянь), который был знатоком китайских законов [6, с. 13]. Он окончил восточный (1900) и юридический (1901) факультеты Санкт-Петербургского университета. Много лет он преподавал в Институте ориентальных и коммерческих наук и Юридическом факультете в Харбине. В Университете Маньчжудиго Г. Г. Авенариус читал лекции по истории Восточной Азии. Он был автором нескольких публикаций, посвящённых юриспруденции: «Исправленное и дополненное положение о судопроизводстве в судебных местах всех разрядов, подведомственных судебным палатам» (Харбин, 1921) и «Положение о судопроизводстве в судебных учреждениях Китая» (Харбин, 1921).

Николай Евгеньевич Эсперов (1893 - после 1945), используя свои лекции, опубликовал в Харбине небольшую монографию «Система выборов в Народное собрание Китая». Его командировали за границу, где он сдал магистерские экзамены по юриспруденции перед Русской Академической группой в Париже (1926). На Юридическом факультете Н. Е. Эсперов был приват-доцентом по кафедре истории русского права и профессором (с янв. 1934). В дальнейшем он развил свои идеи в некоторых публикациях: «Политические партии и представительный строй» (Хар- 
бин, 1931) и «Современная конституция Китая (агитационно-воспитательного периода)» (Харбин, 1931).

Известный харбинский адвокат в Харбине Михаил Эммануилович Гильчер (1874 - после 1945, США) окончил юридический факультет Новороссийского университета, прослушал курс лекций в Германии и Франции. На Юридическом факультете в Харбине Гильчер читал курсы: китайское гражданское право, кодекс, процесс [9, с. 33].

Занятия по курсу «гражданский процесс» вёл адвокат Франц Акселевич Вальден (1871-1943, Шанхай), который был из семьи финских переселенцев в Приморье. Он окончил юридический факультет Санкт-Петербургского университета [2, с. 36].

Член коллегии защитников при Владивостокском окружном суде Константин Георгиевич Зверев был арестован во Владивостоке 1 июля 1927 г. Его выслали из города, и он смог эмигрировать в Китай. Поселившись в Харбине, читал на Юридическом факультете курс «Гражданский процесс».

Специалистом по римскому праву был бывший городской голова Тобольска Михаил Михайлович Шалабанов (1884-1958, Калифорния) [3]. Он закончил юридическое отделение Юридического факультета в Харбине (1925).

Право является потребностью общественного развития, глубоко отражает многие моменты в изменении любого общества. Современное китайское юридическое образование возникло под влиянием внешних сил, его создание и развитие имеют большое практическое значение.

Всякое образование должно интернациональным, особенно это важно для юридического образования. Возникновение и развитие современного китайского юридического образования сыграли очень важную роль в преобразовании современного Китая. Появление Юридического факультета в Харбине привело к значительному обогащению юридической науки в Китае. Это учебное заведение создало платформу для лучшего научного и студенческого обмена, изучения китайского и российского права.

\section{Список литературы}

1. 李, 岱. 黑龙江省高等教育沿革（1902-1985）/岱, 李. - 哈尔滨工业大学出版社, 1989年. - 136页. - Ли, Дай. История развития высшего образования в провинции Хэйлунцзян (1902-1985) / Дай Ли. - Харбин : Издательство Харбинского политехнического университета, 1989. - $136 \mathrm{c.}$

2. Автономов, Н. П. Юридический факультет в Харбине : (исторический очерк), 1920-1937 // Право и культура: Сб. в ознаменование восемнадцатилетнего существования Юридического факультета в г. Харбине. - Харбин, 1938. - С. 36. 
3. Гинс, Г. М. М. Шалабанов : (Некролог) // Русская жизнь. - Сан-Франциско, 1958. - 19 апреля.

4. История Юридического факультета в Харбине: Профессора и питомцы закрывшегося факультета рассеяны по всему свету // Новая заря. -Сан-Франциско, 1938. - 17 марта.

5. К. Н. Проф. Г. Г. Тельберг: (Некролог) // За веру и правду. - Сан-Франциско, 1954. - № 3 (окт.). - С. 50.

6. Памяти Г. Г. Авенариуса : (Некролог) // Политехник. - Сидней, 1976. № 8. - С. 16.

7. 冯子, 寰. 中国近代法律教育研究（1862-1937）. - 吉林大学博士学位论文/ 寰冯子. - 长春, 2019. - 162页. - Фэн, Цзыхуань. Исследование юридического образования в современном Китае (1862-1937) : дис. ... д-р ист. наук / Цзыхуань Фэн. Чанчунь, 2019. - 162 c.

8. 张, 耕. 中国政法教育的历史发展 / 耕张. - 吉林人民出版社, 1995. - 152页. Чжан, Гэн. Историческое развитие китайского политико-юридического образования / Гэн Чжан. - Чанчунь : Изд-во Цзилиньского Жэньминьского чубаньшэ, 1995. - 152 с.

9. 彭传，勇. 哈尔滨俄侨中国学家：生平、活动、著述 / 勇彭传，焕石金. 中国社会科学出版社, 2014. - 133页. - Пэн, Чуаньюн. Китаеведы русских эмигрантов в Харбине: биография, научные деятельности, труды / Чуаньюн Пэн, Цзиньхуань Ши. - Пекин : Издательство Общественных наук Китая, 2014. - 133 с.

10. 朱有, 獻. 中国近代学制史料/獻朱有. - 华东师范大学出版社, 1987。 602页. - Чжу, Юхуань. Исторические материалы по системе образования в современном Китае. - Шанхай : Изд-во Восточно-китайского педагогического университета, 1987. -602 c.

11. 王, 健. 中俄法学教育交流回顾与展望 // 中国大学教学. - 2018年. - 第01. 第92-95页. - Ван, Цзянь. Ретроспектива и перспективы обмена юридического образования между Китаем и Россией // Преподавание в китайском университете. 2018. - № 1. - C. 92-95.

12. 邓建, 新. 中国法学教育的历史与现实. 中国政法大学硕士学位论文/新邓建. 北京, 2006年. - 第34页. - Дэн, Цзяньсинь. История и реальность китайского юридического образования: дис. ... магистра / Цзяньсинь, Дэн. - Пекин, 2006. - 34 с. 


\section{References}

1. Li Dai. History of the Development of Higher Education in Heilongjiang Province (1902-1985). - Harbin: Harbin Polytechnic University Press, 1989. 136 p. (In Chinese).

2. Avtonomov N.P. Yuridicheskii fakul'tet v Kharbine : (istoricheskii ocherk), 1920 1937 [Faculty of Law in Harbin: (Historical essay), 1920-1937]. In: Pravo i kul'tura: Sьорник $v$ oznamenovanie vosemnadtsatiletnego sushchestvovaniya Yuridicheskogo fakul'teta $v$ g. Kharbine [Law and Culture: Sat. to commemorate the eighteen years of existence of Law. fac. in Harbin]. Harbin, 1938, pp. 1-112.

3. Hins G. M. M. Shalabanov : (Nekrolog) [Shalabanov: (Obituary)]. Russkaya zhizn' [Russian life]. San Francisco, 1958. 19 Apr.

4. History of the Faculty of Law in Harbin: Professors and pupils of the closed faculty are scattered all over the world. Novaya zarya [New Dawn]. San Francisco, 1938. 17 March. (In Russian).

5. K. N. Prof. G. G. Telberg: (Obituary). Za veru i pravdu [For faith and truth]. San Francisco, 1954, no. 3 (Oct.), pp. 50. (In Russian).

6. In memory of G. G. Avenarius: (Obituary). Polytechnic. Sydney, 1976, no. 8, pp. 16. (In Russian).

7. Feng Zihuan. Study of legal education in modern China (1862-1937). Doct. Dis. (Histor. Sci). Changchun, 2019. 162 p. (In Chinese).

8. Zhang Geng. Historical Development of Chinese Political and Legal Education. Changchun: Jilin Renmin Chubanshe Publishing House, 1995. 152 p. (In Chinese).

9. Peng Chuanyong, Shi Jinhuan. Sinologists of Russian Emigrants in Harbin: Biography, Scientific Activities, Works. Beijing: China Social Science Press, 2014. 133 p. (In Chinese).

10. Zhu Yuhuan. Historical Materials on the Education System in Modern China. Shanghai: East China Normal University Publishing House, 1987. 602 p. (In Chinese).

11. Wang Jian. Retrospective and prospects for the exchange of legal education between China and Russia. Teaching at the Chinese University, 2018, no 1, pp. 92-95. (In Chinese).

12. Deng Jianxin. History and Reality of Chinese Legal Education. Mag. Dis. Beijing, 2006. 34 p. (In Chinese). 